\title{
Persistent Pupillary Membrane
}

National Cancer Institute

\section{Source}

National Cancer Institute. Persistent Pupillary Membrane. NCI Thesaurus. Code C161555.

A cong enital abnormality of the eye caused by incomplete regression of the tunica vasculosa lentis, which is the vascular structure that nourishes the crystalline lens in utero. 